\title{
Cycle: Forgotten anatomists of small European nations
}

\section{Topic: Pawlík's and Treitz's day}

(C) Springer-Verlag 2009
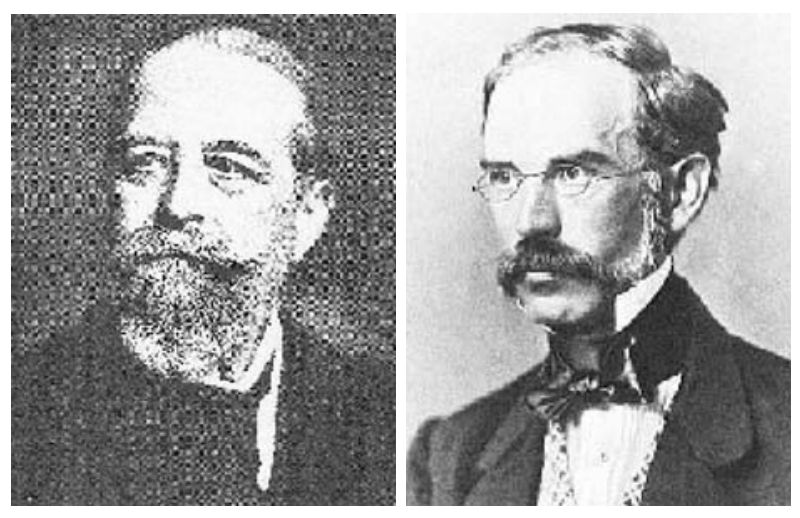

Dear Colleagues,

a commemorative afternoon devoted to the 190th anniversary of the birth of the Czech pathologist Václav Treitz and to the 160th anniversary of the birth of the Czech gynaecologist and obstetrician Karel Pawlík.

will be held on December 9, 2009

from 2 p.m.

at the Syllaba's hall

of the Third Faculty of Medicine,

Charles University in Prague,

Czech Republic

Address: Ruská 87, 100 00, Praha 10, Czech Republic Language: English

Admission free

\section{Conference details}

Cycle: Forgotten anatomists of small European nations Topic: Pawlík's and Treitz's day

A commemorative afternoon devoted to the 190th anniversary of the birth of the Czech pathologist Václav Treitz and to the 160th anniversary of the birth of the Czech gynaecologist and obstetrician Karel Pawlík, featuring also lectures on German gynaecologist and obstetrician Gerhard Leopold and a special topic about Georges Clémenceau.

Date: December 9, 2009

Language: English

Organizer: Department of Anatomy, Department of History of Medicine

Charles University in Prague, Czech Republic

Address: Ruská 87, 100 00, Praha 10, Czech Republic

Language: English

Conference fee: 0

Call for abstracts: Deadline - September 30, 2009

Registration: used email address: david.kachlik@lf3. cuni.cz

Officials: David Kachlík, Pavel Čech

Website: http://old.lf3.cuni.cz/anatomie/veda_konference. htm 